\title{
Quantified vegetation change over 42 years at Cape Hallett, East Antarctica
}

\author{
L. BRABYN ${ }^{1 *}$, C. BEARD ${ }^{1}$, R.D. SEPPELT ${ }^{2}$, E.D. RUDOLPH ${ }^{\dagger}$, R. TÜRK ${ }^{3}$ and T.G.A. GREEN ${ }^{1}$ \\ ${ }^{1}$ University of Waikato, Private Bag 3105, Hamilton, New Zealand \\ ${ }^{2}$ Australian Government Antarctic Division, Channel Highway, Kingston, TAS 7050, Australia \\ ${ }^{3}$ Institut für Pflanzenphysiologie, Universität Salzburg, Hellbrunnerstr. 34, A-5020 Salzburg, Austria \\ ${ }^{\dagger}$ (deceased) Ohio State University, Columbus, OH 43212-1157, USA \\ *larsb@waikato.ac.nz
}

\begin{abstract}
This paper reports on the remapping of a carefully documented vegetation plot at Cape Hallett $\left(72^{\circ} 19^{\prime} \mathrm{S} 170^{\circ} 16^{\prime} \mathrm{E}\right)$ to provide an assessment of the rates of vegetation change over decadal time scales. E.D. Rudolph, in 1962, mapped in detail the vegetation of a site approximately $28 \mathrm{~m}$ by $120 \mathrm{~m}$ at Cape Hallett, Victoria Land, Antarctica. This site was relocated and remapped in January 2004 and changes were assessed using GIS techniques. This appears to be the longest available time period for assessing vegetation change in Antarctica. The analysis indicated that considerable change had occurred in moss and algae distribution patterns and this seems to have been caused by increased water supply, particularly in wetter areas. There was also evidence of some change in lichen distribution. The extent of the change indicates that vegetation cover can be used for monitoring change in areas as extreme as the Ross Sea region. For this analysis to be successful it was important that the mapping techniques used were totally explicit and could easily be replicated. Fortunately, Rudolph had defined his cover classes and the site was also clearly marked. The application of GIS mapping techniques allows the mapping to be more explicitly defined and easily replicated.
\end{abstract}

Received 14 December 2005, accepted 31 July 2006

Key words: algae, GIS, GPS, growth, Latitudinal Gradient Project, lichen, moss, Victoria Land

\section{Introduction}

Climate change is predicted to impact first and most severely in the higher latitudes (Callaghan et al. 1992, Kennedy 1995, Vincent 1997, Walker 1997). Antarctic vegetation, which is entirely poikilohydrous and dominated by algae, bryophytes and lichens in the continental Antarctic areas covered by this paper, is thought to be particularly sensitive to climate change (Robinson et al. 2003). Community structure is simpler than in lower latitudes and has been almost completely unaffected by direct anthropomorphic influences and introductions. In particular, the vegetation is often suggested to be at the physiological limit of survival and might be expected to be more sensitive to environmental changes than communities in less extreme conditions. The Antarctic could, therefore, be one of the more significant baseline environments for the study of global climate change (Smith 1990, Walton et al. 1997).
It is interesting to consider what might be the major drivers of future vegetation change in continental Antarctica. It is very unlikely that changes in environmental factors such as increased incident radiation and ultraviolet radiation will have much effect. Most mosses and lichens studied appear to be well protected against full sunlight (Kappen et al. 1998, Pannewitz et al. 2003b) and can rapidly respond to changes in UV levels (Newsham et al. 2002, Green et al. 2005). Temperature is the obvious first candidate and there is no doubt that a cline in terrestrial biodiversity occurs with increase in latitude in Antarctica (Green et al. 1999). However, the majority of this cline takes place along the Antarctic Peninsula and it appears that, on the main continent, we are dealing with biodiversity that is controlled to an increasing extent by microclimate and becomes more and more confined to suitable sites as latitude and environmental extremes increase. This is very similar to the situation that occurs as one moves above the

\section{Dedication}

This paper is dedicated to the memory of E.D. Rudolph, a pioneer in the study of vegetation in continental Antarctica. Rudolph, as part of the United States Antarctic program, was at Cape Hallett for three seasons from 1961 to 1964. Rudolph died in 1992 and we are indebted to Dr R.L. Stuckey who carefully archived Rudolph's research material, including all photographic slides, in the Herbarium of Ohio State University, an example of the value of archiving in Antarctic research. 
tree line into the alpine zone of mountain areas (Körner 2003). The extent of the vegetation within these microsites and, in particular, the rate or extent of growth could well be strongly linked to temperature (Green et al. 1999). It has been shown that mosses collected from the field in Antarctica can grow rapidly producing up to $50 \%$ increase in cover if kept under favourable conditions of light and moisture at $2^{\circ} \mathrm{C}$, for $8-19$ weeks, and $18^{\circ} \mathrm{C}, 2-3$ weeks, (Melick \& Seppelt 1997). The potential for growth when conditions are improved obviously exists.

For continental Antarctica it is accepted that vegetation distribution is predominantly determined by moisture availability (Schwarz et al. 1992, Kennedy 1993, Green et al. 1999) linked to microtopography (Schwarz et al. 1992, Melick \& Seppelt 1994). Changes in precipitation could have several effects, both positive and negative. Increased snow fall could negatively affect vegetation by maintaining the cold winter temperatures and preventing activity leading to death of the lichens and mosses (Gannutz 1971, Pannewitz et al. 2003a). Decreased precipitation would lead to even greater aridity and an expected decline in vegetation diversity and abundance (Robinson et al. 2003). Rising temperatures might also cause greater moisture availability through increased melt. This would be expected to improve growth conditions but could have different effects on the various organisms. Algae are most common in areas with high water availability, usually flooding or flowing, mosses in areas with reliable but not deep water and lichens avoid wet, inundated conditions (Schwarz et al. 1992). Thus, changes in water supply could alter the relative abundance of the different groups as well as possibly increasing vegetation extent and altering biodiversity (Robinson et al. 2003).

At present, the information available to allow us to detect and measure change is very small. In the Ross Sea region there appears to be no published evidence that change in vegetation is occurring. In fact, there is an underlying belief that growth of mosses and lichens is very slow and changes in distribution will, therefore, also be minor at least over the short to medium term. Although sites are now being established that should allow change to be detected (Cannone et al. 2004), at present we cannot even say that alteration in vegetation cover or growth occurs at a rate that would allow us to detect or monitor climate change. We have in the Ross Sea region no published growth rate for mosses. Growth rates for mosses at Edmonson Point $\left(74^{\circ} 20.0^{\prime} \mathrm{S} 165^{\circ} 08.0^{\prime} \mathrm{E}\right)$ were reported to be up to 3.6, 4.6 and $3.5 \mathrm{~mm} \mathrm{yr}^{-1}$ for Bryum argenteum Hedw., B. pseudotriquetrum (Hedw.) Gaertn., Meyer et Scherb. and Ceratodon purpureus (Hedw.) Brid., respectively, in their optimal environments, but are based on an assumption (length of green part of shoot equals annual growth rate) that has not been proved (Smith 1999). Mean growth rates over four years have been published for the Windmill Hills region $\left(66^{\circ} 18^{\prime} \mathrm{S}, 110^{\circ} 33^{\prime} \mathrm{E}\right)$ of 2.4 and $3.2 \mathrm{~mm} \mathrm{yr}^{-1}$ for
Grimmia antarctici Card. and B. pseudotriquetrum, respectively (Melick \& Seppelt 1997). Much higher growth rates are reported for both bryophytes and lichens from the Antarctic Peninsula and sub-Antarctic islands, with the moss Calliergidium austrostramineum (C. Muell.) Batr. reaching up to $32 \mathrm{~mm} \mathrm{a}^{-1}$ (Longton 1988).

A first step, therefore, is to establish that change occurs at a sufficient pace to allow climate change to be detected. Then we can attempt to determine the rate of change and obtain some idea of what might be driving the change. With this information we should be able to establish improved and more reliable methods to monitor and detect future change (Howard-Williams et al. 2006).

In this paper we make use of a detailed vegetation map of a $120 \mathrm{~m}$ by $28 \mathrm{~m}$ plot located at Cape Hallett (170¹4'2.56"E, 72¹9'11.5"S), Victoria Land, Antarctica that was produced by E.D. Rudolph in 1962 (Rudolph 1963). The site of the mapped area was rediscovered in December 1999, by a visiting Waikato University group who found marker stakes to still be in place. The main aim of our research was to remap this plot in January 2004 and quantitatively assess the change that has occurred in the vegetation during the previous 42 years. An additional objective was to analyse these changes in relation to the physical characteristics of the surface of the plot, such as rock type, wetness, and slope. The published version of the map (Rudolph 1963) is of such low quality that it could not be used for any comparisons. However, the original of the map and related notes were stored and archived by Dr Ron Stuckey in the herbarium of Ohio State University after the untimely death of Rudolph in 1992. These originals were of excellent quality and were copied for the purposes of this work.

\section{Methods}

\section{Research site description}

Cape Hallett $\left(72^{\circ} 19^{\prime} \mathrm{S} 170^{\circ} 16^{\prime} \mathrm{E}\right)$ is located at the southern end of Moubray Bay, northern Victoria Land, in the western Ross Sea at the northern tip of the north-south aligned Hallett Peninsula. Projecting about $1200 \mathrm{~m}$ west from the high rocky ridge forming Cape Hallett is Seabee Hook, a low, generally less than $5 \mathrm{~m}$ above sea level, recurved spit composed of coarse volcanic material, of between 130 and $575 \mathrm{~m}$ wide, with a total area of approximately 41.1 ha. Hallett Station was established on Seabee Hook in 1957 and operated, in later years as summer only, until finally abandoned in February 1973.

Cape Hallett is close to the northernmost extent of the western Ross Sea coast line which extends southwards a further $14^{\circ}$ latitude (to $86^{\circ} \mathrm{S}$ ). The site thus represents an important northern anchor point for studies investigating changes in vegetation with latitude in continental Antarctica and the Ross Sea region, in particular. Climatically, it is close to, but cooler than, sites on the continental coastline to 
Table I. Mean annual, January and January maximum temperatures for Cape Hallett, selected stations at a similar latitude and Scott Base within the Ross Sea. In all cases the data are from records spanning over 40 years with the exception of Cape Hallett where they are for 1957-1964.

\begin{tabular}{lccccc}
\hline & & \multicolumn{3}{c}{ Mean temperature ( $\left.{ }^{\circ} \mathrm{C}\right)$} \\
Site & $\begin{array}{c}\text { Latitude } \\
\text { South }\end{array}$ & $\begin{array}{c}\text { Longitude } \\
\text { East }\end{array}$ & Annual & January & $\begin{array}{c}\text { January } \\
\text { maximum }\end{array}$ \\
\hline Casey & $66^{\circ} 17^{\prime}$ & $110^{\circ} 32^{\prime}$ & -9.3 & -0.1 & +1.8 \\
Dumont d'Urville & $66^{\circ} 40^{\prime}$ & $140^{\circ} 00^{\prime}$ & -10.7 & -0.9 & +0.8 \\
Mawson & $67^{\circ} 36^{\prime}$ & $62^{\circ} 52^{\prime}$ & -11.2 & +0.1 & +2.5 \\
Davis & $68^{\circ} 35^{\prime}$ & $77^{\circ} 58^{\prime}$ & -10.1 & +0.9 & +3.1 \\
Cape Hallett & $72^{\circ} 19^{\prime}$ & $170^{\circ} 13^{\prime}$ & -15.4 & -1.4 & +0.8 \\
Scott Base & $77^{\circ} 51^{\prime}$ & $77^{\circ} 46^{\prime}$ & -19.9 & -4.8 & -1.6 \\
\hline
\end{tabular}

the west [Table I, US Weather Bureau (1962-65)]. In comparison to Dumont d'Urville, the closest site with longterm climate records, the annual mean temperature $\left(-15.4^{\circ} \mathrm{C}\right)$ is $4.4^{\circ} \mathrm{C}$ cooler, the January mean $\left(-1.4^{\circ} \mathrm{C}\right) 0.4^{\circ} \mathrm{C}$ cooler but the absolute maximum temperature is identical at $+0.8^{\circ} \mathrm{C}$. The mean temperature is $4.5^{\circ} \mathrm{C}$ warmer than at Scott Base, just over five degrees latitude further south. Additional information about the site can be found in Sinclair et al. 2006a, 2006b.

Rudolph's plot occupies an area mostly of flat gravel and cobble on the eastern side of Willett Cove within the Antarctic Specially Protected Area No. 106 (originally Specially Protected Area No. 7) and is located with its southern part at the base of scree slopes that extend up onto the ridge of the Hallett Peninsula approximately $300 \mathrm{~m}$ above (Figs 1 \& 2). Large rocks located on the plot suggest occasional falls but there appear to have been no new large rock falls on the plot since Rudolph's visit in 1962 (Fig. 2).

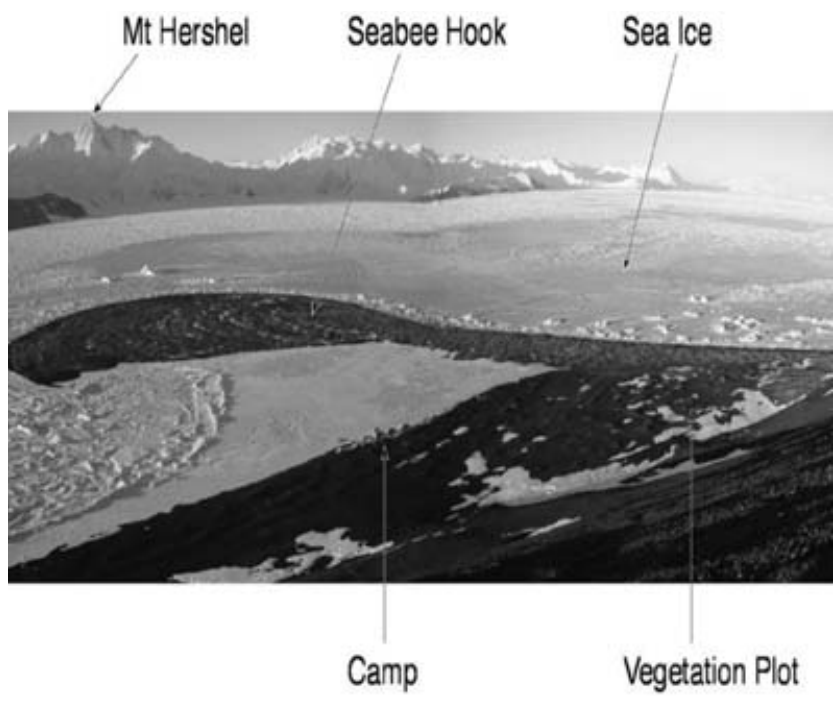

Fig. 1. Photograph of the Cape Hallett area showing the location of the plot mapped by Rudolph in 1962. The majority of the area of Seabee Hook and to the north of the plot site is occupied by an Adélie penguin colony. Willet Cove remains frozen for most years.

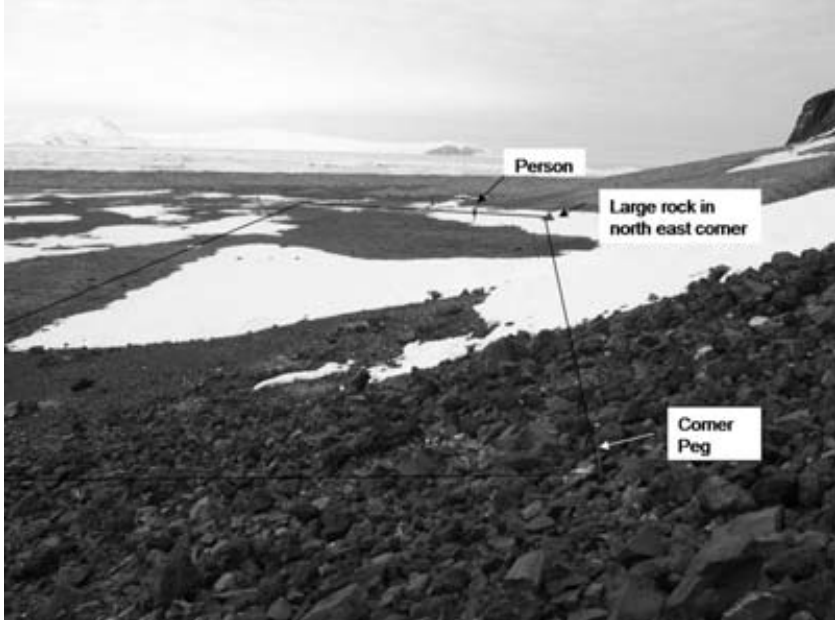

Fig. 2. A photograph taken looking due north showing the general relief of the Rudolph vegetation plot. To the right is a steep scree slope whilst the majority of the plot occupies a relatively flat and very wet area. Note the size of the figure and the large rock marking the north-east corner of the plot. The other corners of the plot are marked by large steel pegs (south-east corner peg can be seen) as, also, is the western border.

The plot was found in 1999 because some of the original marker pegs still remain on the site. ASPA No. 106 includes a large Adélie penguin colony (22 000 pairs in 2002) situated on Seabee Hook. South Polar skuas also frequent the area and the last skua census, conducted in January 1983, counted 84 breeding pairs (Pascoe 1984). Clearly fauna must be impacting the flora within the plot through nutrients from excrement, trampling, nest building, and a significant input of atmospheric ammonia from the Adélie penguin colony. Although the plot is protected from unauthorised human visits because of its location within the Specially Protected Area it has no special status and additional protection will be sought.

\section{Vegetation}

The area in the vicinity of the study plot is a flat pebbly/cobble beach terrace (Harrington \& McKellar 1958) which is, at least in part, very wet because of poor drainage, meltwater input from elevated snow fields, ephemeral snow deposition, and sub-surface ice melt. There is considerable ponding during the summer and the area is traversed by many ephemeral drainage courses. This is an area with locally abundant algae, mosses and lichens. Moss and algal patches are particularly extensive, especially in the northwestern parts, adjacent to the base of the scree slope where areas in excess of tens of square metres may have almost complete cover. Elsewhere they are more scattered but still common. In the wettest areas there is a dominance of green algae e.g. Prasiola crispa (Lightf.) Meneghini, Protococcus sp., and cyanobacteria (e.g. Nostoc). Only one species of moss, Bryum subrotundifolium Jaeg., Ber. S. Gall, is present 
Table II. Mosses and lichens found in the Rudolph plot at Cape Hallett. The list for algae and cyanobacteria is incomplete.

Lichens:

Amandinea petermannii

Buellia frigida Darb.

Caloplaca sp.

Caloplaca citrina (Hoffm.) Th. Fr.

Caloplaca saxicola (Hoffm.) Nordin Algae and cyanobacteria:

Candelaria murrayi

Candelariella flava (L.) Th. Fr.

Lecanora expectans Darb.

Physcia caesia (Hoffm.) Hampe.

Physcia dubia (Hoffm.) Lettau

Xanthoria mawsonii Dodge

in the beach terrace moss beds and in the Rudolph plot. Outside these areas Bryum pseudotriquetrum and B. subrotundifolium occur in a mixed moss bed on sand and cobble in the lower scree slopes at the southern end of the beach. Three other moss species, Ceratodon purpureus, Sarconeurum glaciale Card. \& Bryhn, and a Grimmia sp. were collected on either the rock outcrops of the upper scree slope or from the ridge tops above. High nutrient levels from the large colony of Adélie penguins and from skua gulls may limit moss and lichen biodiversity. The dominance of $B$. subrotundifolium is similar to the situation at Beaufort Island where pure B. subrotundifolium stands occur in an area significantly influenced by breeding and roosting skuas (Seppelt et al. 1999). In total, 11 species of lichen and one moss were collected from the Rudolph plot in January 2004 (Table II).

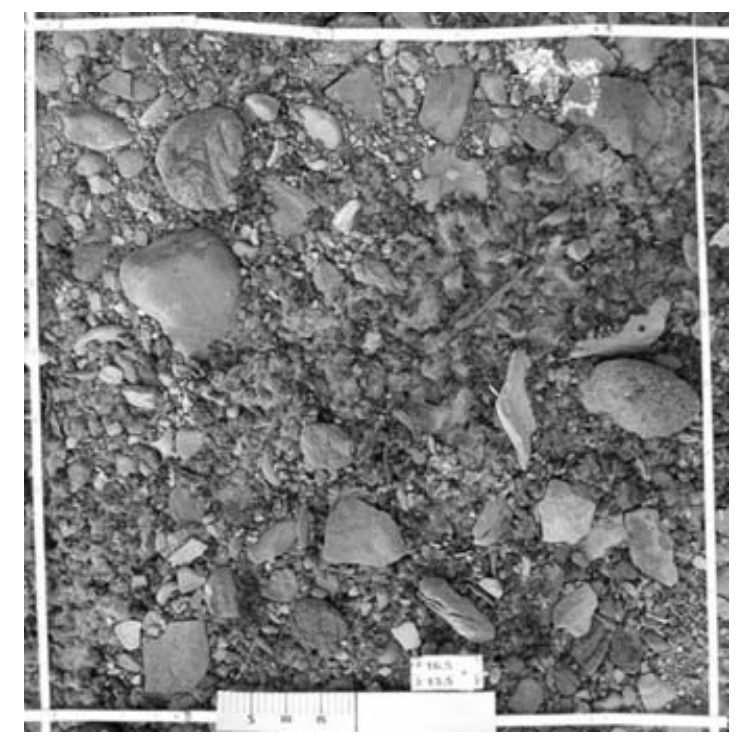

Fig. 3. A typical photograph taken of a single, one square metre area that was the basis of the mapping of the plot in 2004. A total of 120 such cells were photographed and archived at Antarctica New Zealand.

\section{Rudolph's map and digitisation}

In its published format, Rudolph's vegetation map does not provide detailed spatial information (Rudolph 1963). A full scale paper copy of the original map and associated field notes made by Rudolph were obtained from archives at Ohio State University where they are archived in the herbarium at the Museum of Biological Diversity. The distance unit of Rudolph's original map is feet. The copy of the map was digitised into a GIS layer and converted to metric units. Hard copy maps were reproduced with a $2 \mathrm{~m}$ grid overlay (neat lines) to enable easy geographic referencing in the field.

Rudolph's original map shows many boulders on the plot that form distinctive relative configurations which could be easily located in the field. On the assumption that these boulders had not shifted, which is likely to be the case given that their relative configurations were the same, they were used as geographic reference (control) points to test the accuracy of the digitised map. The grid references of 21 boulders were carefully measured in the field and from the digitised map. A comparison of the boulder locations showed differences of up to one metre, which is problematic for accurate vegetation change analysis. The observed discrepancies are most likely due to differences in tape measurements in the field. From his diaries it appears that Rudolph had to use short measuring tapes rather than the long continuous tapes that were used in 2004. Given the length of the plot $(120 \mathrm{~m})$, the windy Antarctic conditions, skuas, and wandering curious penguins that easily catch their feet in the tape, it is quite probable that there could be positional differences in the location of the tapes. Another cause of difference could have been introduced during the digitising of the original hard copy map.

With GIS it is possible to correct these errors by adjusting ("rubber sheeting") the GIS layer using the boulder locations as control points. This worked effectively and it was estimated that the spatial error was reduced to $10 \mathrm{~cm}$. The effect of this map adjustment was that the GIS version of Rudolph's map of the plot was no longer rectangular (this can be seen in Fig. 4). The total area of the plot was $3387 \mathrm{~m}^{2}$ and the area under snow was $158 \mathrm{~m}^{2}$ in 1962 and $1524 \mathrm{~m}^{2}$ in 2004.

\section{Transferring Rudolph's vegetation classes.}

Even though Rudolph's class definitions are quantitative and are clearly defined using a percentage threshold, some definitions still require subjective judgement. When calculating the density of vegetation, it is necessary to work out the percentage cover within a defined area. A subjective judgement is then required to determine the extent or boundary of the defined area, in other words, it necessary to identify a boundary in order to determine the density boundary. Rudolph's estimates of vegetation cover boundaries were based on subjective judgements on the 


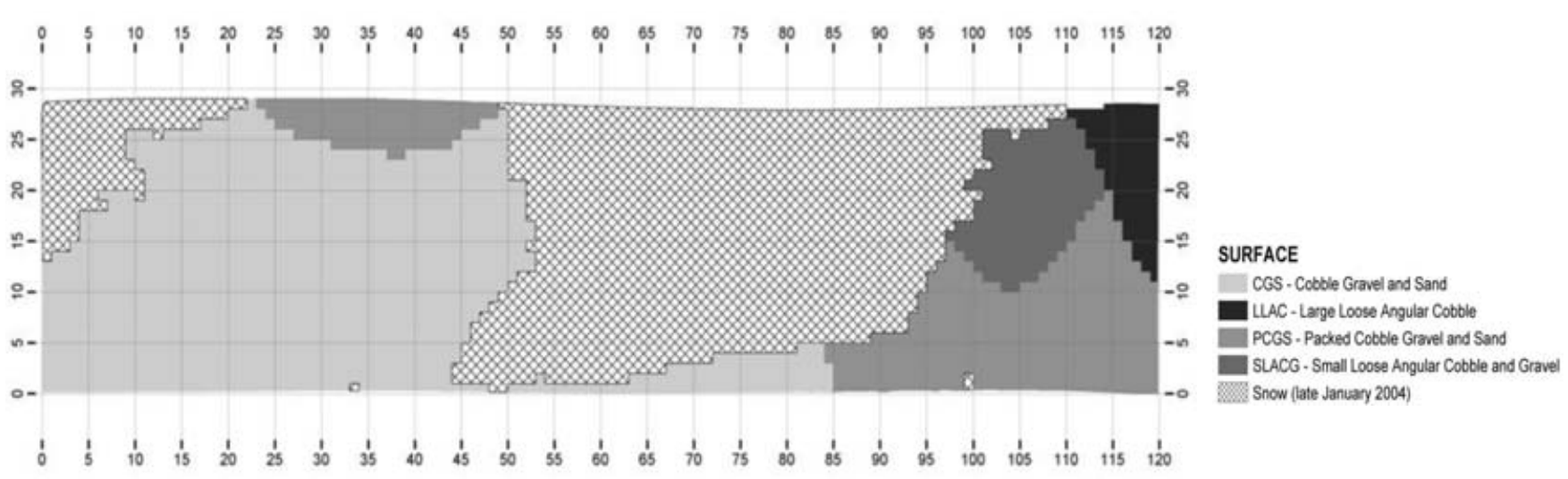

Fig. 4. The surface detail of the Rudolph vegetation plot. Each one metre square that was not covered by snow was allocated to one of the four categories describing the surface (described in text). Note how the upper border, in particular, is no longer straight as a result of the correction applied by the "rubber sheeting” GIS processing.

change of vegetation density. Where possible the boundaries would have been based on abrupt changes in vegetation density but when there are subtle changes, such as the difference between scattered and patchy vegetation, the method is unclear. In cartographic terms Rudolph's map is described as dasymetric, because the vegetation classes in the plot determine the boundaries shown on the map. Because the creation of this dasymetric map was subjective, it is difficult to replicate precisely. Predefined boundaries, which are relatively independent of the map maker, are necessary to maintain objectivity and repeatability. In cartographic terms this is known as choropleth mapping.

Rudolph's map classifies the cover of mosses, lichens, and algae into four classes: Heavy (40-100\%), Patchy (10-40\%), Scattered (less than 10\%), and None (0\%). Combinations of these classes were then used to describe the vegetation and Rudolph's map contains 31 vegetation classes which consist of various density combinations of algae, moss and lichen, which are difficult to portray in a small map. These were prepared for GIS analysis by disaggregating his class descriptions so that there was a separate column (field) for each of the vegetation types. For example, instead of having one field that described the vegetation as "scattered moss and patchy lichen", separate fields for the moss, lichen and algae were used. For this particular example, the moss field contained "scattered", the lichen field "patchy", and the algae field "none". The important fact that Rudolph defined his classes in terms of percentage cover meant that it was possible to convert his classifications to categories that could be used in mapping.

\section{Remapping the vegetation plot in 2004}

In the field, the plot was accurately located from the original marker pegs that remain on the site (Fig. 2). On the northeast corner of the plot is a large rock, which can be identified on an aerial photograph taken in 1983. A local coordinate (grid) system with the north-west corner of the plot as the origin (real world coordinates $170^{\circ} 14^{\prime} 2.56 " \mathrm{E}$, $72^{\circ} 19^{\prime} 11.5 " \mathrm{~S}$ ) was used for geo-referencing points within the plot. Tape measures were laid out from this point along the plot boundaries.

Rudolph's plot was remapped using predetermined $1 \mathrm{~m}^{2}$ units. To achieve a detailed level of mapping it is necessary to use small units; however, the disadvantage of this is that more data must be recorded. Given that the plot size is $3387 \mathrm{~m}^{2}, 1 \mathrm{~m}^{2}$ units (cells) seemed a suitable compromise. Further, estimations of the percentage vegetation cover within even smaller units is then relatively easy by visually dividing each unit into smaller parts (such as $25 \mathrm{~cm}^{2}$ units) and summing the finer units to estimate the percentage cover.

The percentage cover of mosses, lichens and algae were recorded within each cell. If the vegetation type was present in a cell but less than $1 \%$ it was recorded as $1 \%$. The $\mathrm{x}, \mathrm{y}$ distance of the cell centre from the plot origin (north-west corner) was also recorded together with a description of the surface rock, percentage snow cover, and slope. Four different surface rock types were identified and are described as follows:

1. Packed angular cobble mixed with gravel, sand, (PCGS) organic matter, and scattered large boulders. The slope of this rock type surface was less than five degrees.

2. Cobble, gravel and sand (CGS) with slope less than five degrees.

3. Small loose angular cobble and gravel (SLACG), associated with a former penguin colony mound with a slope of 15 degrees.

4. Large loose angular cobble (LLAC) with patchy organic skua debris and at the base of a scree slope. The slope of this rock type surface was 22 degrees.

Data collected in the field were stored in Microsoft Excel, converted to a Dbase file, and then imported to a GIS point 
layer using the xy locations as the geographical coordinates. The GIS used was Arc/Info 8.0 (Environmental Systems Research Institute, California, USA). A one metre raster grid of the plot was generated and converted to a polygon layer. Using a point in polygon overlay function, the recorded xy data was stored as a polygon layer. Each one metre square polygon therefore contained information on the percentage cover of mosses, lichens and algae as well as surface characteristics, unless it was under snow. This resulted in a new map of Rudolph's plot.

A series of digital colour images were also taken of selected $1 \mathrm{~m}^{2}$ within the plot by holding a digital camera directly above the centre of the cell. Figure 3 provides an example of such an image. These images will be useful for future remapping of the plot because it will enable future observers to see how different cells were interpreted in 2004 and hence calibrate their own assessments to the percentage cover classes used in 2004. It will also allow small-scale changes to be detected. Although the intention at first was to obtain digital images of the whole plot in this way, time constraints meant only 120 cells were imaged.

\section{Vegetation change analysis}

Using GIS, vegetation change was quantified by combining the two digital maps using a polygon on polygon overlay. This generated a polygon layer that contained all the information of both maps in a single database. The density of the vegetation types for 1962 and 2004 were then compared and the differences in area of the different vegetation classes were quantified. Change was also recorded as either increase, decrease, or no change. These comparisons were only made for areas that were free of snow for both of the recordings $\left(55 \%, 1871 \mathrm{~m}^{2}\right)$.

\section{Results}

\section{Surface characteristics}

There is a trend from the smaller grained cobble, gravel and sand in the wetter, lower north-west side of the plot to the larger, loose, angular cobble forming the more steeply sloping base of the scree slopes making up the upper southeast end of the plot (Fig. 4). The drier, but not part of the scree, areas have packed cobble, gravel and sand. The wet
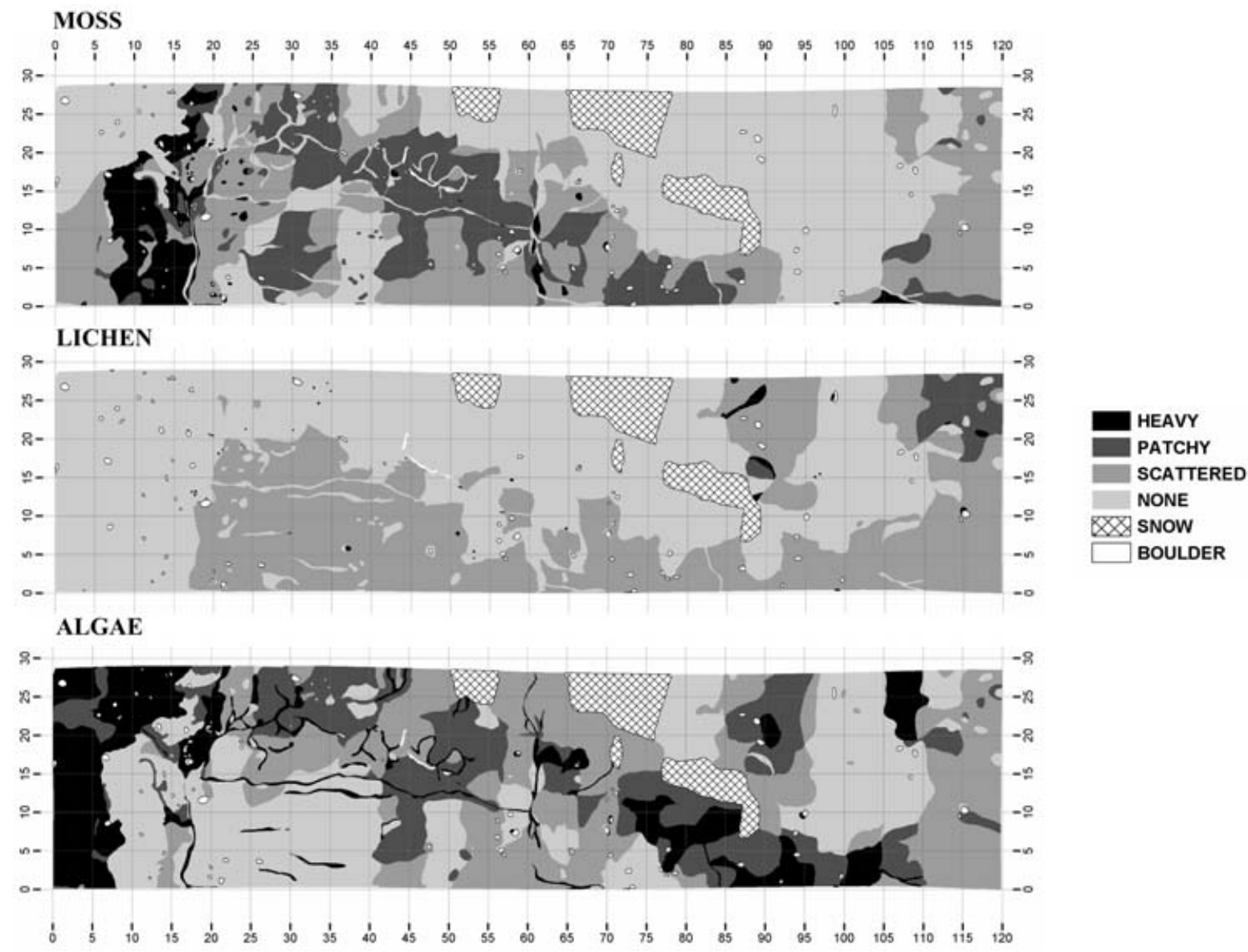

Fig. 5. The original map from Rudolph in 1962 prepared for GIS analysis by disaggregating his class descriptions so that each of the vegetation types (moss, lichen or alga) can be presented separately. The four cover categories are those of Rudolph (1963) and are - Heavy (40-100\%), Patchy (10-40\%), Scattered (less than 10\%), and None (0\%). 
areas, unless frozen, are difficult to walk across because of the soft nature of the substrate. The terrain would be expected to have a large influence on the vegetation types because of the standing water and higher moisture levels in the lower, flatter north-western part of the plot as compared to the upper south-eastern side with its drier, but possibly unstable, and more rocky lower parts of the scree.

\section{Vegetation cover 1962}

The map as drawn by Rudolph was disaggregated into separate categories for lichens, algae and mosses and the distributions based on Rudolph's cover estimates are shown in Fig. 5. Most of the cover is by algae and moss with lichens having a cover value of none or scattered except for the drier, higher parts of the plot. Algae have the highest cover and both algae and moss are most extensive in the north-west wetter areas. This distribution is not unexpected and fits with that of Rudolph (1963) and is as found in other areas of Antarctica (Melick \& Seppelt 1994).

\section{Vegetation cover 2004}

The vegetation cover as mapped in 2004 is shown in Fig. 6. Unfortunately snow still covered a much larger part of the plot (45\%) than when Rudolph mapped it but, of the area that could be mapped, algae covered $31.4 \%$, moss $12.5 \%$, and lichens $1.6 \%$ (Table III). Of the $590.0 \mathrm{~m}^{2}$ covered with algae, 90\% occurred on the CGS (cobble gravel and sand) although this substrate only composed $62.5 \%$ of the mapped area. Moss showed a similar distribution with $85.3 \%$ being on CGS whilst only $23.6 \%$ of the lichen cover occurred there. CGS dominates the lower, wetter part of the plot (Fig. 4). PLGS (packed cobble gravel and sand), a drier zone that made up $24.2 \%$ of the mapped area contained 8.8 , 13.8 and $34.4 \%$ of the algae, moss and lichen, respectively. In contrast, $34.4 \%$ of the lichen cover (total $30.5 \mathrm{~m}^{2}$ ) occurred on LLAC (large loose angular cobble) although that substrate made up only $4.4 \%$ of the mapped area. The proportions for moss and algae on LLAC were $0.01 \%$ and $0.5 \%$, respectively. The preferences shown by lichens for the higher, drier and more rocky parts of the plot, and the algae and moss for the lower, wetter parts are very clear.

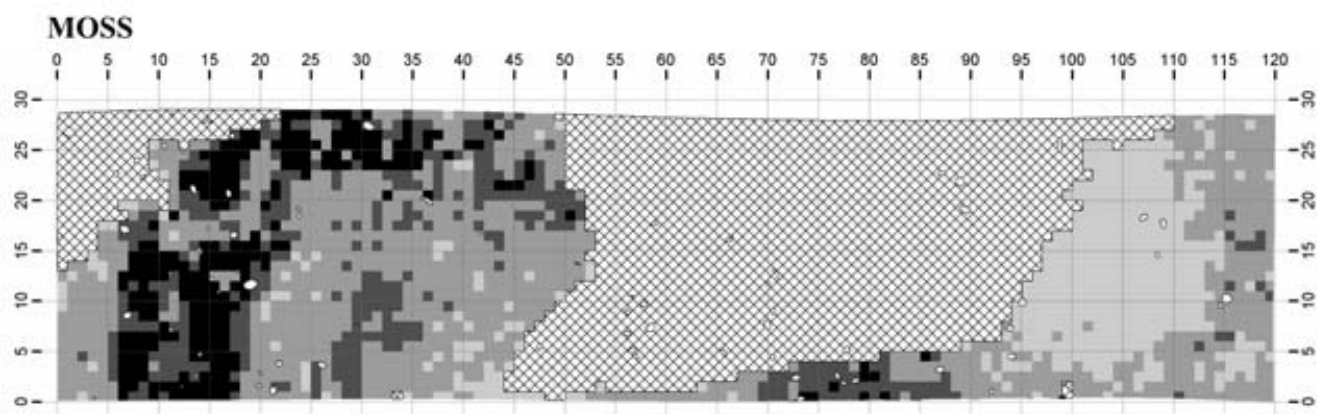

\section{LICHEN}
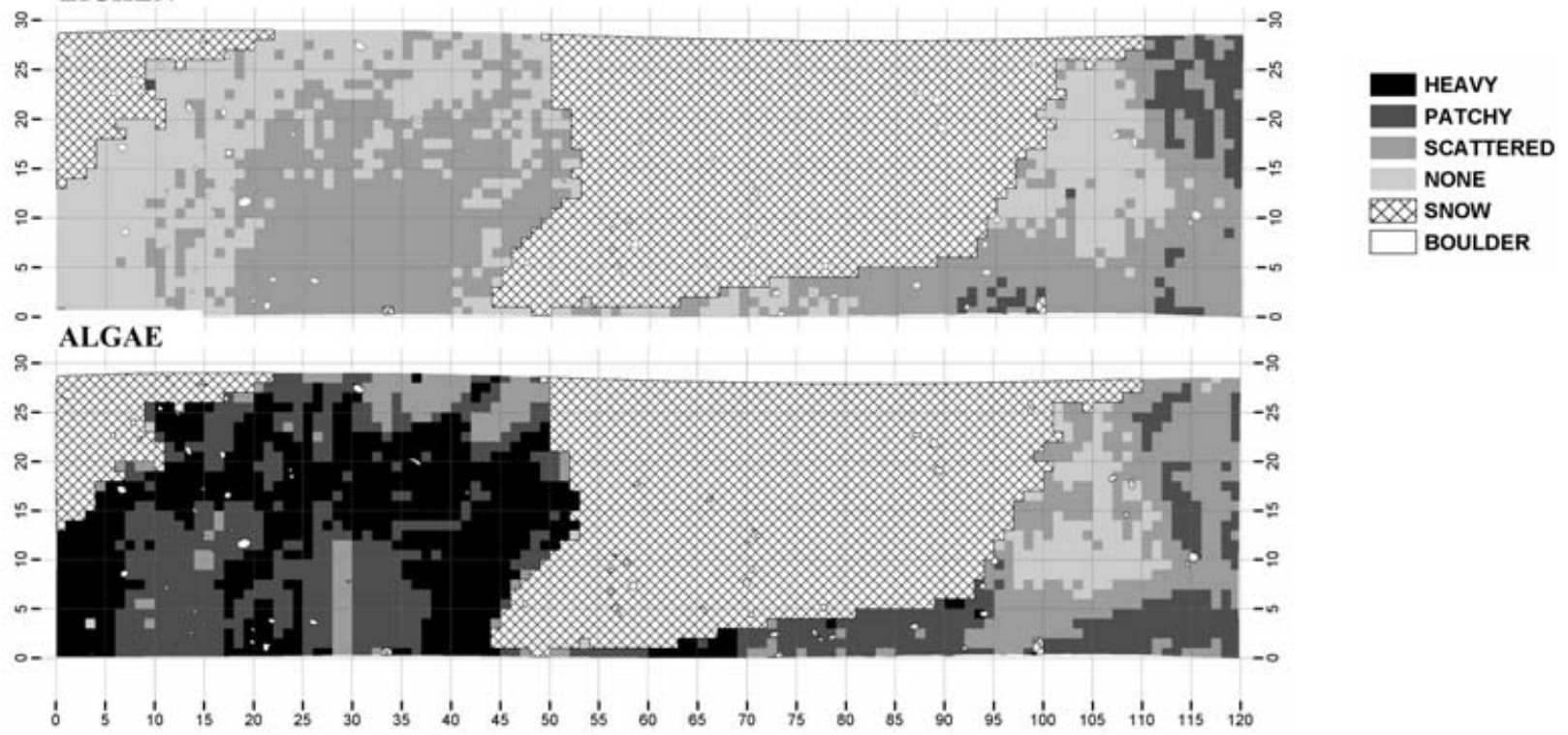

Fig. 6. The results of mapping the plot in 2004 using the same categories as Rudolph (see Fig. 5) for the three different vegetation types. Note that the snow covered area is more extensive in 2004 and fully overlaps the snow cover when Rudolph prepared his map. 
Table III. Area and percent cover of vegetation type by surface type of the Rudolph Plot in 2004. CGS = Cobble gravel and sand, LLAC = Large loose angular cobble, PCGS = Packed angular cobble mixed with gravel and sand, SLACG = Small loose angular cobble and gravel.

\begin{tabular}{lrrrrrrr}
\hline $\begin{array}{l}\text { Surface } \\
\text { excludes }\end{array}$ & total & moss & lichen & algae & moss & lichen & algae \\
snow) & & & & & & & \\
\hline ALL & 1879.9 & 234.7 & 30.5 & 590.0 & 12.5 & 1.6 & 31.4 \\
CGS & 1178.1 & 200.1 & 7.2 & 530.8 & 17.0 & 0.6 & 45.1 \\
LLAC & 83.3 & 1.9 & 10.5 & 4.4 & 2.3 & 12.7 & 5.3 \\
PCGS & 453.5 & 32.5 & 10.2 & 51.7 & 7.2 & 2.3 & 11.4 \\
SLACG & 165.0 & 0.2 & 2.6 & 3.1 & 0.1 & 1.6 & 1.9 \\
\hline
\end{tabular}

\section{Changes in cover between 1962 and 2004}

Overlaying of the Rudolph cover values with those from 2004 allows the change in each mapped square to be calculated separately for algae, moss and lichen combined with each cover category (Table IV and Fig. 7). The area with no cover has decreased for all surface types and vegetation types, indicating that overall the vegetation cover on the plot has expanded. A change (increase or decrease) has occurred in at least one of the vegetation types in most of the plot. Only 13\% (243 $\left.\mathrm{m}^{2}\right)$ of the plot that was surveyed had remained the same for all three vegetation types. Since 1962 28\% of the algal covered area showed no change in cover and the equivalent values for mosses and lichens were $49 \%$ and $72 \%$, respectively. When the whole plot is examined, the algal cover has changed the most. The increase in area with heavy algal cover was particularly large at $356 \mathrm{~m}^{2}$.

The extent of these changes varied with the surface type (Table IV). CGS showed the most change in cover for moss and algae. This change is not surprising given that the area is flat and ephemerally flooded from nearby snow melt, as well as trampled by penguins. There was $531 \mathrm{~m}^{2}$ of algal cover on CGS in 2004 and only $20 \%$ of this was at the same density as recorded in 1962. There was a more than doubling of the area with heavy algal cover (up $215 \mathrm{~m}^{2}$ ) whilst cells with no algae practically disappeared (down $98.8 \%$, Table IV). There was a large increase in the heavy moss cover $\left(30.3 \%, 48.7 \mathrm{~m}^{2}\right)$ and scattered moss cover $\left(57.9 \%, 226.2 \mathrm{~m}^{2}\right)$. In contrast the extent of patchy moss decreased by $23.2 \%$ so that, of the $370 \mathrm{~m}^{2}$ of patchy moss on CGS in 1962, over half of this $\left(194 \mathrm{~m}^{2)}\right.$ became scattered or no moss. We can be certain that these increases result from the expansion of moss colonies and by recruitment because we are able to compare photographs of a site in the GGS taken in 1962 (Rudolph archive) and by us in 1999 (Fig. 8). The expansion of the Bryum subrotundifolium onto bare ground around the stone is clear. This species is well known to produce abundant deciduous apical shoots which are obviously very successful for colonizing new areas. For the lichens, 74\% of the CGS surface had no change in density. However, the cover of lichen was very small $(0.6 \%$ in 2004). It is reasonable to conclude that vegetation cover on
Table IV. Change in area by different vegetation classes and surface types between 1962 and 2004. CGS = Cobble gravel and sand, LLAC = Large loose angular cobble, PCGS = Packed angular cobble mixed with gravel and sand, SLACG = Small loose angular cobble and gravel.

\begin{tabular}{|c|c|c|c|c|c|c|c|}
\hline \multirow[b]{2}{*}{$\begin{array}{l}\text { Surface } \\
\text { type }\end{array}$} & \multirow[b]{2}{*}{$\begin{array}{l}\text { Cover } \\
\text { category } \\
\text { (Rudolph) }\end{array}$} & \multicolumn{3}{|c|}{$\begin{array}{c}\text { AREA in } 1962 \\
\left(\mathrm{~m}^{2}\right)\end{array}$} & \multicolumn{3}{|c|}{$\begin{array}{c}\text { Change (1962-2004) } \\
\%\end{array}$} \\
\hline & & Moss & Lichen & Algae & Lichen & Moss & Algae \\
\hline \multirow[t]{4}{*}{ ALL } & None & 612.9 & 962.2 & 777.7 & -18.3 & -34.6 & -82.9 \\
\hline & Scattered & 650.1 & 826.9 & 460.2 & 19.1 & 37.7 & -10.4 \\
\hline & Patchy & 438.6 & 76.1 & 336.0 & 32.6 & -24.9 & 100.1 \\
\hline & Heavy & 166.8 & 3.2 & 294.6 & -100.0 & 47.3 & 121.8 \\
\hline \multirow[t]{4}{*}{ CGS } & None & 246.6 & 643.8 & 541.8 & -19.1 & -76.1 & -99.8 \\
\hline & Scattered & 390.6 & 524.4 & 235.6 & 24.1 & 57.9 & -73.6 \\
\hline & Patchy & 369.7 & 0.0 & 181.2 & 0.0 & -23.2 & 160.2 \\
\hline & Heavy & 162.4 & 1.0 & 210.7 & -100.0 & 30.3 & 202.2 \\
\hline \multirow[t]{4}{*}{ LLAC } & None & 23.6 & 5.7 & 21.5 & -100.0 & -62.5 & -92.9 \\
\hline & Scattered & 57.4 & 16.6 & 57.7 & 47.3 & 24.4 & 15.6 \\
\hline & Patchy & 2.2 & 59.7 & 4.0 & -1.5 & 34.4 & 273.7 \\
\hline & Heavy & 0.0 & 0.0 & 0.0 & 0.0 & 0.0 & 0.0 \\
\hline \multirow[t]{4}{*}{ PCGS } & None & 207.9 & 198.7 & 94.9 & -26.9 & -11.7 & -30.4 \\
\hline & Scattere & 173.6 & 250.0 & 151.7 & 11.5 & 9.8 & 25.9 \\
\hline & Patchy & 64.1 & 0.6 & 140.2 & 4122.5 & -34.2 & 26.1 \\
\hline & Heavy & 4.4 & 0.7 & 63.2 & -100.0 & 667.8 & -73.8 \\
\hline \multirow[t]{4}{*}{ SLACG } & None & 23.6 & 5.7 & 21.5 & -100.0 & -62.5 & -92.9 \\
\hline & Scattered & 57.4 & 16.6 & 57.7 & 47.3 & 24.4 & 15.6 \\
\hline & Patchy & 2.2 & 59.7 & 4.0 & -1.5 & 34.4 & 273.7 \\
\hline & Heavy & 0.0 & 0.0 & 0.0 & 0.0 & 0.0 & 0.0 \\
\hline
\end{tabular}

the CGS part of the plot has been highly dynamic with significant fluctuations in moss and algal cover probably resulting from ephemeral water flows.

A similar, dynamic situation appears to have occurred on the packed angular cobble mixed with gravel, and sand (PCGS) surface, although to a lesser degree and to variable extents depending on the cover category. This surface was flat but slightly more elevated so it was unlikely to experience the same degree of ephemeral flooding from nearby snow melt. Vegetation cover was lower overall and all three vegetation types are predominantly scattered throughout this area. Areas with no cover declined for all vegetation types and were matched by somewhat similar increases in the scattered categories. Cover levels in the patchy and heavy categories were low and this led to some spectacular changes even if small in absolute terms. Although heavy moss increased by $667.8 \%$, this was actually only $34 \mathrm{~m}^{2}$ or $7.5 \%$ of the PCGS area. Overall there was an increasing trend on this surface type.

The large loose angular cobble (LLAC) is the least represented surface (4.4\% of the total surveyed) but has the highest level of lichen cover (12.7\% in 2004, Table III) compared to $2.3 \%$ and $5.3 \%$ for moss and algae, respectively. Although lichen cover has not changed in approximately half the area, there was a substantial increase (47.3\%) in the scattered category which represents a gain of 


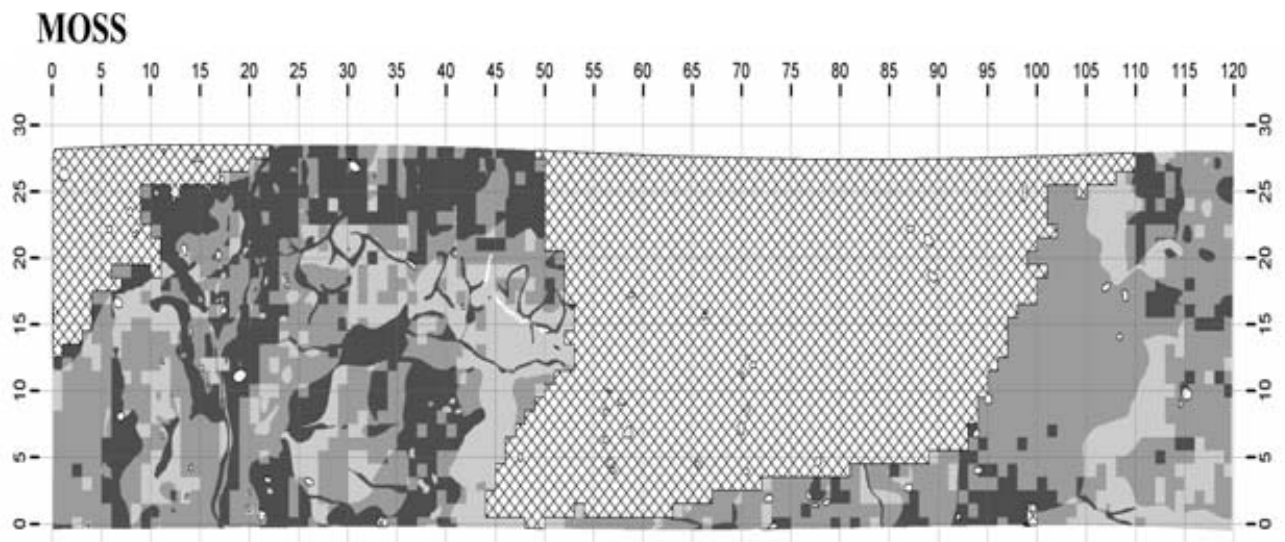

\section{LICHEN}
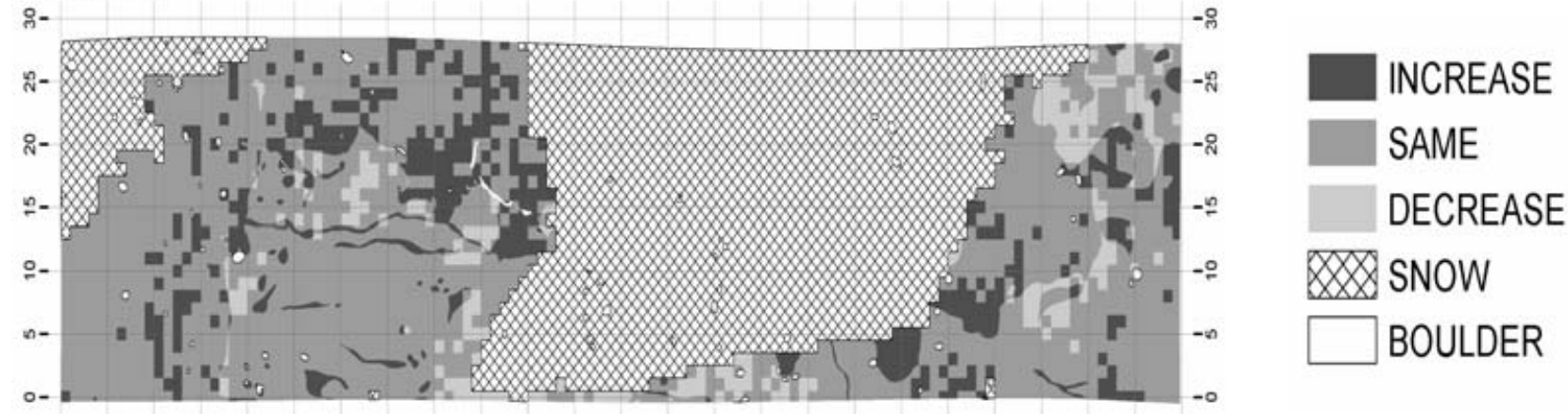

\section{ALGAE}

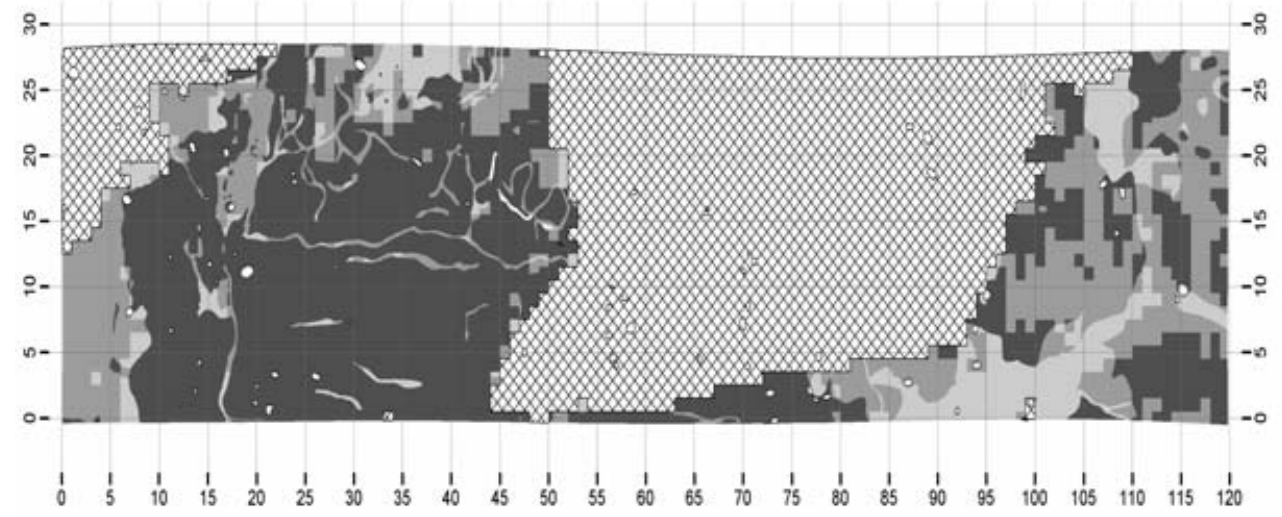

Fig. 7. Change in cover of the three vegetation types (moss, lichen and alga) between 1962 and 2004. This map has been prepared using GIS techniques to overlay the map from1962 (Fig. 5) and that from 2004 (Fig. 6) and then computing the differences for each cell (one square metre). Results are given as increase, decrease or no change.

$7.9 \mathrm{~m}^{2}$, or about $10 \%$ of this surface type.

The small loose angular cobble and gravel (SLACG) surface was the least vegetated of all the surface types. The moss and algae are mostly scattered and this is at the lower end of the scattered cover range, which explains why the percentage cover for moss and algae in 2004 was only $0.1 \%$ and $1.9 \%$, respectively. For most of this surface the moss and lichen did not change although the small amount of algae on this surface had increased in patches.

\section{Discussion}

The plot at Cape Hallett originally marked and mapped by E.D. Rudolph in 1962 (Rudolph 1963) represents a unique resource for monitoring vegetation change in Antarctica. Following the remapping in 2004 we can now be certain that changes in vegetation cover do occur at a rate that allow their use for monitoring changes in local and global climate. In fact the changes in the vegetation of the plot have been extensive and allow some analysis of what has happened (Fig. 7). Only $13 \%$ of the surveyed area showed no 


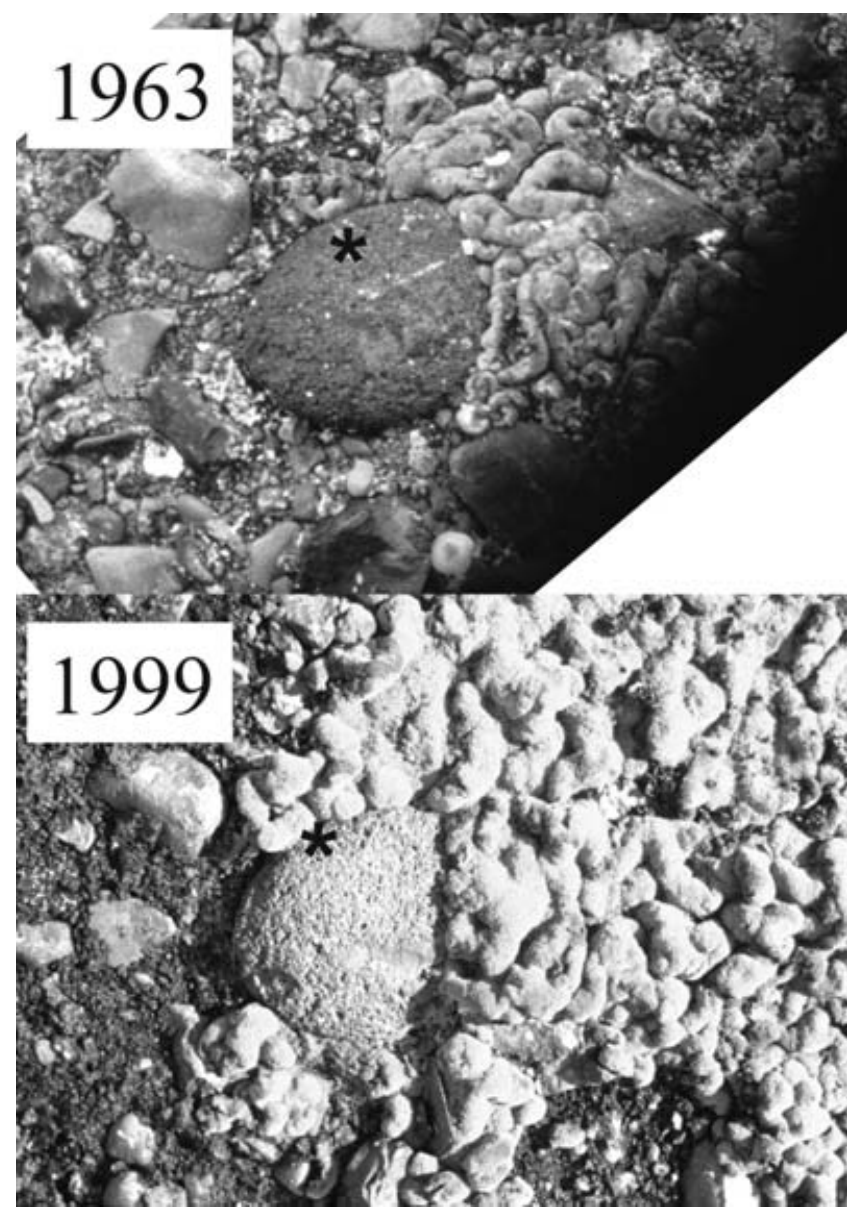

Fig. 8. Photographs from 1964 (lower panel, taken by Rudoph) and 1999 (upper panel) of the same rock showing the large increase in moss cover. The asterisks mark a moss clump (immediately above the asterisk) which is present in both 1964 and 1999. In other places (at the top of the picture) there has been new colonisation and growth by the moss (Bryum subrotundifolium).

detectable change at all. Most obvious is that areas with no previously recorded cover of lichen, moss or alga have reduced markedly (by 18.3, 34.6 and 82.9\% respectively) indicating a general expansion. Changes in algal cover have been particularly marked with an increase of $356 \mathrm{~m}^{2}$ (out of a total $1880 \mathrm{~m}^{2}$ ) in the heavy cover category (40-100\% cover). Overall, increases in cover were 31.4, 12.6 and $1.6 \%$ for algae, moss and lichen, respectively. There is no doubt that change has occurred and has been substantial. The photograph showing increased moss cover over 36 years (1963 to 1999, Fig. 8) unequivocally confirms that increases in cover have occurred and that the changes found by comparing the two maps are real.

It is also possible to get a fairly clear idea of what has been the primary driver of this change. The original survey by Rudolph (1963) and the resurvey in 2004 both show linkages between the distribution of the main vegetation types and local habitat conditions. Algae are present in the
Table V. Area $\left(\mathrm{m}^{2}\right)$ and proportion (\%) of vegetation that has decreased, increased or remained constant for the different surface types between 1962 and 2004. CGS = Cobble gravel and sand, LLAC = Large loose angular cobble, PCGS = Packed angular cobble mixed with gravel and sand, SLACG = Small loose angular cobble and gravel.

\begin{tabular}{llrrrrrr}
\hline Surface & & \multicolumn{2}{c}{ Moss } & \multicolumn{2}{c}{ Lichen } & \multicolumn{2}{c}{ Algae } \\
Type & Change & $\mathrm{m}^{2}$ & $\%$ & $\mathrm{~m}^{2}$ & $\%$ & $\mathrm{~m}^{2}$ & $\%$ \\
\hline All & Decrease & 400 & 21 & 168 & 9 & 227 & 12 \\
& Increase & 549 & 29 & 360 & 19 & 1112 & 60 \\
& No change & 919 & 49 & 1341 & 72 & 530 & 28 \\
CGS & Decrease & 280 & 24 & 90 & 8 & 48 & 4 \\
& Increase & 388 & 33 & 213 & 18 & 884 & 76 \\
& No change & 501 & 43 & 867 & 74 & 237 & 20 \\
LLAC & Decrease & 5 & 6 & 20 & 24 & 5 & 6 \\
& Increase & 21 & 25 & 19 & 23 & 28 & 34 \\
& No change & 57 & 69 & 44 & 53 & 51 & 61 \\
PCGS & Decrease & 85 & 19 & 29 & 6 & 145 & 32 \\
& Increase & 129 & 29 & 107 & 24 & 133 & 30 \\
& No change & 236 & 52 & 314 & 70 & 172 & 38 \\
SLACG & Decrease & 28 & 17 & 29 & 18 & 29 & 18 \\
& Increase & 11 & 7 & 20 & 12 & 67 & 41 \\
& No change & 124 & 76 & 115 & 71 & 69 & 42 \\
\hline
\end{tabular}

very wet areas, moss (in this case only B. subrotundifolium) in areas with a regular water supply and lichens in the drier, rocky sites. This is certainly not a novel discovery and agrees with other published material on vegetation distribution at sites relevant to Cape Hallett such as Windmill Islands (Melick \& Seppelt 1994) and Edmonson Point (Smith 1999). Predictions suggest that any increase in water availability will lead to greater cover with the largest response from those vegetation types inhabiting the wetter areas (Robinson et al. 2003).

The large increase in both the area with alga present and in alga cover density, together with similar, though smaller, changes for the moss, all point to an increase in water availability particularly over the lower, more poorly draining part of the plot. It appears that the area containing substantial, even standing or ephemeral flooding, water has markedly increased. This can be the result of increased melt, itself a result of increased precipitation and/or warmer temperatures, or it could indicate blockage to the drainage outside the plot area. The water itself comes from snow patches on the scree and from the ice field on the plateau at the top of the scree. A comparison of photographs of the scree taken from about the same location and time of the year in 1963 and 1999 suggest little change in snow patch location or extent. Long-term temperature records for the Ross Sea region show few signs of increasing temperature. We are, therefore, unable with any certainty to correlate the increased water availability with change in climate. Only more careful observations at more frequent intervals will allow changes in water flow through damming to be excluded. The only certain results are that there has been a major change in the vegetation and, as suggested by the 
large increase in algal cover, that this was probably driven by increased water availability.

Although we have no comparative rates for the growth of algae, moss and lichen in the Ross Sea region, it is reasonable to assume that the different increases in cover represent inherent differences in the vegetation groups to colonise and expand. There is little doubt that the algae can grow in extent most rapidly and, where water availability increases, then moss will also outgrow the lichen. Thus, although the plot, overall, was very dynamic the areas of greatest change were those that were the wettest. It is also likely that those areas that are most rapidly able to recover from damage will be those that are wetter.

The 42 year period between surveys has enabled us to detect and prove the occurrence of vegetation change. However, it is a long period and another level of change may exist within the overall cover values. Observation on the site shows that the depths of the cushions formed by $B$. subrotundifolium are not that variable and are normally around 20-40 $\mathrm{mm}$ in thickness. In the absence of substantially thicker moss cushions it seems possible that there may be a structural limit for the moss cushion thickness above which they become unstable and then breakdown or are removed. It is known from observations on B. subrotundifolium patches at Canada Glacier, Taylor Valley, at Edmonson Point (Smith 1999) and at Cape Hallett, that the desiccated plants are not attached to the underlying substrate and are easily detached and removed. At Cape Hallett it was not uncommon to see small patches of moss floating in the first water flows. It is probable that a dynamic equilibrium occurs, rather than a fixed distribution with increasing mat thickness. We are unable to calculate any exact growth rates from this survey. However, examination of the moss in Fig. 8 shows that some cushions are new during the 42 year period whilst others can be recognised in both photographs (black asterisk in Fig. 8). This suggests that actual moss shoot growth is probably less than $1 \mathrm{~mm} \mathrm{a}^{-1}$ at Cape Hallett (assuming a cushion thickness of not more than $40 \mathrm{~mm}$ ).

Within the plot there is a cross section of different surface types, and this study has shown that significant differences in vegetation cover, and change in that cover, occurs between these surfaces. The degree of stability between these surfaces also varies significantly. If study plots such as this have, as their objective, the monitoring of climate change, then it will be necessary to choose surface types that support vegetation but are less prone to ephemeral flooding and disturbance. Rudolph's plot is not likely to be representative of other vegetated areas in the Cape Hallett region, simply because it is close to the sea and this is often close to open water in the summer, there is a large penguin colony nearby (with its associated ammonia and nutrient input as well as physical disturbance) and skuas are nesting on the site. There may also be very few similar areas that experience the same extent of ephemeral flooding.

Such a large heterogeneous study plot $(120 \mathrm{~m} \mathrm{x} 28 \mathrm{~m})$ is also a large area to map in detail. Having one large plot means that considerable time is spent on one area, and this area may not be very representative of the region, as is certainly the case with Rudolph's plot. The advantage of Rudolph's plot, however, is easy access. To improve representation of different vegetation types and to better detect change, future studies in Antarctica should use a number of smaller plots.

The use of GIS has made vegetation change analysis much easier and more accurate to implement. The ability to adjust the maps to known control points ensures that the same locations are being compared. Field records can now be entered in to a spreadsheet directly in the field, and the transition to a map takes only a few minutes using a GIS and automation techniques. The analysis for this project was completed entirely in the field only a few hundred metres from the study site. This meant that the results of the research were available immediately and could be interpreted on site. It also meant that the sampling technique could be rapidly developed and tested, thus making it much easier to apply. The ability of GIS to overlay two separate maps and quantifiably compare the two maps is a powerful function that is considerably quicker than manual techniques.

This vegetation comparison using a 42 year baseline time frame was only achievable because Rudolph's notes, map, and images had been archived at Ohio State University. The GIS layers, digital photos, and hard copy maps generated from this research will be archived with the University of Waikato, Hamilton, New Zealand, and also Antarctica New Zealand, Christchurch.

\section{Acknowledgements}

We would like to thank the following organisations and people for assisting with this research; Antarctica New Zealand for the logistical support for this event, Shulamit Gordon for enthusiastically co-ordinating the Latitudinal Gradient Project and enabling this research to occur, Rachel Brown and Gus McAllister for managing the Latitudinal Gradient Project field camp at Cape Hallett, Paul Beere and Christian Schoen for digitising maps, Ohio State University for access to their archival records and providing copies of the original map, images and associated notes, Australian Antarctic Division for logistic support in the initial relocation survey of the study site in 1999/2000, The University of Waikato and, especially, Professor Bryan Gould, Vice-Chancellor at the time, for his continued interest in, and financial support of, the programme. We also thank the referees for their helpful comments. 


\section{References}

Callaghan, T.V., Sonesson, M. \& Somme, L. 1992. Response of terrestrial plants and invertebrates to environmental change at high latitudes. Philosophical Transactions of the Royal Society of London, B338, 279-288.

CANnone, N. 2004. Moss and lichen flora of Victoria Land (Continental Antarctica) along a latitudinal transect. Terra Antartica, 11, 1-10.

GANNUTZ, T.P. 1971. Ecodynamics of lichen communities in Antarctica. In QuAm, L., ed. Research in the Antarctic. Washington, DC: American Association for the Advancement of Science, 213-226.

Green, T.G.A., Kulle, D., Pannewitz, S., Sancho, L.G. \& Schroeter, B. 2005. UV protection in mosses growing in continental Antarctic. Polar Biology, 28, 822-827.

Green, T.G.A., Schroeter, B. \& SAncho, L. 1999. Plant life in Antarctica. In Pugnaire, F.I. \& Valladares, F., eds. Handbook of functional plant ecology. New York: Marcel Dekker, 496-543.

HARRINGTON, H.J. \& McKelLAR, I.C. 1958. A radiocarbon date for penguin colonization of Cape Hallett, Antarctica. New Zealand Journal of Geology and Geophysics, 1, 571-576.

Howard-Williams, C., Peterson, D., Lyons, W.B., Cattaneo-Vietti, R. \& GoRdon, S. 2006. Measuring ecosystem response in a rapidly changing environment: the Latitudinal Gradient Project. Antarctic Science, 18, 465-471.

Kappen, L., Schroeter, B., Green, T.G.A. \& Seppelt, R.D. 1998. Chlorophyll $a$ fluorescence and $\mathrm{CO}_{2}$ exchange of Umbilicaria aprina under extreme light stress in the cold. Oecologia, 113, 325-331.

KenNEDY, A.D. 1993. Water as a limiting factor in the Antarctic terrestrial environment: a biogeographical synthesis. Arctic and Alpine Research, 25, 308-315.

KenNEDY, A.D. 1995. Antarctic terrestrial ecosystem response to global environmental change. Annual Review of Ecology and Systematics, 26, 683-704.

KÖRNER, C. 2003. Alpine plant life. Berlin: Springer, 338 pp.

LONGTON, R.E. 1988. The biology of polar bryophytes and lichens. Cambridge: Cambridge University Press, 391 pp.

Melick, D.R. \& SePpelt, R.D. 1994. Seasonal investigations of soluble carbohydrates and pigment levels in Antarctic bryophyte and lichens. The Bryologist, 97, 13-19.

Melick, D.R. \& SePPelt, R.D. 1997. Vegetation patterns in relation to climatic and endogenous changes in Wilkes Land, continental Antarctica. Journal of Ecology, 85, 43-56.

Newsham, K.K, Hodgson, D.A., Murray, A.W.A., Peat, H.J. \& SMith, R.I.L. 2002. Response of two Antarctic bryophytes to stratospheric ozone depletion. Global Change Biology, 8, 972-983.

Pascoe, J.G. 1984. Census of the south polar skua at Cape Hallett, Antarctica. Notornis, 31, 312-319.
Pannewitz, S., Schlensog, M., Green, T.G.A., Sancho, L.G. \& Schroeter, B. 2003a. Are lichens active under snow in continental Antarctica? Oecologia, 135, 30-38.

Pannewitz, S., Green, T.G.A., Scheidegger, C., Schlensog, M. \& Schroeter, B. 2003b. Activity pattern of the moss Hennediella heimii (Hedw.) Zand. in the Dry Valleys, Southern Victoria Land, Antarctica during the mid-austral summer. Polar Biology, 26, 545-551.

Robinson, S.A., WASLey, J. \& Tobin, A.K. 2003. Living on the edge plants and global change in continental and maritime Antarctica. Global Change Biology, 9, 1681-1717.

RudOLPH, E.D. 1963. Vegetation of Hallett station area, Victoria Land, Antarctica. Ecology, 44, 585-586.

Schwarz, A.-M.J., Green, T.G.A. \& Seppelt, R.D. 1992. Terrestrial vegetation at Canada Glacier, Southern Victoria Land, Antarctica. Polar Biology, 12, 397-404.

Seppelt, R.D., Green, T.G.A. \& Skotnicki, M. 1999. Notes on the flora, vertebrate fauna and biological significance of Beaufort Island, Ross Sea, Antarctica. Polarforschung, 66, 53-59.

Sinclair, B.J., Scott, M.B., KlOK, C.J., Terblanche, J.S., Marshall, D.J., Reyers, B. \& Chown, S.L. 2006a. Determinants of terrestrial arthropod community composition at Cape Hallett, Antarctica. Antarctic Science, 18, 303-312.

Sinclair, B.J., Terblanche, J.S., Scott, M.B., Blatch, G.L., KLOK, C.J. \& Chown, S.L. 2006b. Environmental physiology of three species of Collembola at Cape Hallett, north Victoria Land, Antarctica. Journal of Insect Physiology, 52, 29-50.

SмITH, R.I.L. 1990. Signy Island as a paradigm of biological and environmental change in Antarctic terrestrial ecosystems. In HEMPEL, G., ed. Antarctic ecosystems, ecological change and conservation. Heidelberg: Springer, 32-50.

SмIтH, R.I.L. 1999. Biological and environmental characteristics of three cosmopolitan mosses dominant in continental Antarctica. Journal of Vegetation Science, 10, 231-242.

US Weather Bureau. 1962-1965. Climatological data for Antarctic stations, January-December Number 1-7. Washington, DC: US Department of Commerce.

VINCENT, W.F. 1997. Polar desert ecosystems in a changing climate: a north-south perspective. In. Lyons, W.B., Howard-Williams, C. \& HAWES, I., eds. Ecosystem processes in Antarctic ice-free landscapes. Rotterdam: Balkema, 3-14.

WALKER, B.H. 1997. Preface: global change and terrestrial ecosystems: the GCTE research programme for the Arctic. In SveinBJornsson, B., ed. Global change and Arctic terrestrial ecosystems. New York: Springer, v-xii.

Walton, D.W.H., Vincent, W.F., Timperley, M.H., HaWes, I. \& HowardWiLliams, C. 1997. Synthesis: polar deserts as indicators of change. In Lyons, W.B., Howard-Williams, C. \& Hawes, I., eds. Ecosystem processes in Antarctic ice-free landscapes. Rotterdam: Balkema, 275-279. 